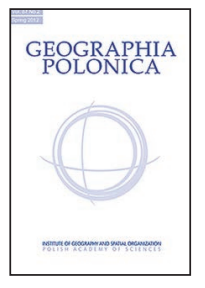

\title{
THE ROLE OF COMPETENCES FOR GEOGRAPHY HIGHER EDUCATION IN UNIVERSITY-TO-WORK TRANSITION
}

\section{Danuta Piróg}

Faculty of Geography

Pedagogical University in Kraków

Podchorążych 2, 30-084 Kraków: Poland

e-mail: dbutryn@up.krakow.pl

\begin{abstract}
The objective of the article is to empirically verify the impact of assessing one's own competences on the transition of recent university geography graduates from education to employment. The article also looks at the role of competences in predicting graduates' situation on the job market. A Poland-wide survey $(N=1120)$ was conducted which collected detailed data on self-assessment of one's competences by students nearing graduation. A follow-up survey six months after graduation showed that only a high assessment of one's own specialised competences had a somewhat significant impact on finding a job that would match one's degree, pay reasonably well and give independence in exercising one's duties at work. Discriminant function analysis was used to establish that the skills which had the greatest impact on whether the geographer remains unemployed or finds employment included socio-emotional and generic competences such as public speaking, team cooperation, precision, attention to detail and interpersonal communication skills. The research suggests, however, that given the current situation on the Polish labour market, these competences are not a key determining feature in the respondents' transition to employment. Moreover, the set of competences does not comprise of variables that allow us to easily predict graduates' situation on the labour market.
\end{abstract}

\section{Key words}

competences $\bullet$ graduate $\cdot$ geography $\bullet$ higher education $\cdot$ labour market $\bullet$ transition

\section{Introduction}

University-to-work transition is considered to be one of the most important processes in every person's life. It is entry into fullyfledged adulthood for university graduates. In this context, university graduates are a special group of people because they and their families spend the largest volume of resources in building their competence capacity. The skills that were supposed to ensure a smooth and satisfactory transition to the labour market required either private means in the case of paid education or public resources in cases where the person studied free of charge. Investments in university education are often 
seen as a means to acquire such competences and skills that will make graduates soughtafter on the job market, help them find their first job quickly and generally facilitate satisfactory career development (Vaatstra \& Vries 2007). Virtually unrestricted access to higher education, slower economic development and caution or even resistance of academic milieus towards the idea of implementing the concept of employability into the educational process results in increasing difficulties in finding a fully satisfying job after graduation, or any job at all for that matter. Currently, in countries affected by the highest unemployment, a decision to take up a university degree is often considered to be an insurance policy of sorts which should protect us from the threat of unemployment (Fernández 2006; Korka 2010). Others consider it to be a strategy to wait until the difficult time on the labour market passes (Piróg 2013). Consequently, in the majority of developed countries, there has been an oversupply of university degree holders who possess a certain set of skills, competences ${ }^{1}$ and qualifications ${ }^{2}$. This massification of higher education translates into the mass availability of competences acquired at higher education institutions (Kivinen \& Ahola 1999) and overeducation (Reimer \& Steinmetz 2009; Barone $\&$ Ortiz 2011). Given the oversupply of competences, it is unrealistic to believe in the successful transition of all graduates; in particular a mismatch often occurs between the supply and demand for certain skills (e.g. Garcia-Aracil \& Van der Velden 2008; Nunez \& Livanos 2010; McGuinness \& Sloane 2011). Other issues include a failure to transfer the acquired skills and utilise them during employment (e.g. Jackson 2013) or a gap between a formal diploma which claims the graduate

\footnotetext{
1 Competences - a set of traits, skills, and attitudes which distinguish a subject and allow his/her functioning in professional settings to be predicted with high probability.

2 Qualifications - skills required in a given sector or occupation, often specific for a given profession or position (e.g. wood processing skills in wood or construction industry, skills of working with talented pupils in the teacher's profession).
}

possesses a certain set of competences and the actual mastery of these competences (Kryńska 2011). Literature reviews show that it has not yet been established which competences have the greatest impact on success on the labour market, when we define success as a relatively smooth and satisfactory transition from education to professional employment (Freire \& Teijeiro 2010; Teijeiro et al. 2013). More and more graduates experience difficulties finding a job which triggers serious economic, social and psychological consequences. Universities are subject to ever increasing pressure to 'produce' graduates who will be capable of successful transition (Bridgstock 2009). Candidates, on the other hand, have doubts and difficulty in finding reasonable justification that the decision to take up higher education was a right one.

The outlined processes lead to a number of questions, e.g. does investing in higher education which equips geography students with certain competences bring the expected benefits, i.e. does it facilitate the smooth and satisfactory transition of graduates to the labour market? Do competences actually determine finding the first job after graduation in the light of an oversupply of degree holders and an economic downturn? If yes, then to what extent? What types of competences of geography graduates affect successful labour market entry?

The article tries to answer the questions based on the Polish example. Poland is a country where after a long period of when the role of education in shaping one's career was underappreciated (up until the political transformation of 1989), society's faith in the value of educational capital $^{3}$ has recently been revived. This enthusiasm returned only to be quickly replaced by a sense of scepticism towards the benefits offered by a higher education diploma. Nowadays, many draw conclusions that a university degree not only does not guarantee attractive employment,

3 Educational capital - documented and certified resources in the form of knowledge and skills, accumulated by a person during education (Turska 2014; Barwińska-Małajowicz 2015). 
but that it has ceased to protect from unemployment (Rachwał 2011; Piróg 2013).

The objective of the article is to perform an empirical verification of the role of competences in the transition of recent graduates to employment based on the example of geography graduates. The study investigates the situation of graduates at the beginning of their professional career, e.g. approximately six months after graduation, by:

- analysing the impact of self-assessment of one's competences on their situation and conditions of employment;

- establishing how significant specific competences are in determining whether the graduate will become employed or remain unemployed.

\section{University graduates' competences versus their situation on the labour market in the light of existing research}

Interest in graduates' competences on the labour market has increased since the Bologna process, but research in this field dates back much longer. Academic analyses of graduates' competences as a determining feature of professional success commenced in the 1970s. The focus was first on the behaviour of graduates in a given profession and position (McClelland 1973). In the years to come, it became clear among researchers specialising in graduates that it is the competences that should constitute the foundation of any research into how universities perform and what their contribution to facilitating graduates' transition to the labour market is (Cabrera et al. 2005).

Literature reviews show various approaches towards research into competence types and their impact on transition. This is due to the fact that competences are multidisciplinary and can be investigated from the point of view of different disciplines of study and in relation to various groups of graduates on the labour market. Because of this diversity, competences are defined in a variety of ways and categorised into a variety of groups (Heijke et al. 2003). Consequently, there is no consensus as to which classification should be universally used in research. What is more, difficulties in collecting empirical data has lead to the fact that it is usually the available data that determines the type of categories used (Garcia-Aracil et al. 2004; Garcia-Aracil \& Van der Velden 2008).

To summarise the area of competences vs. graduates' situation on the labour market, one needs to say that a lot of attention has been put into generic and vocational competences - both in terms of theoretical and empirical research. There have been studies which have looked into the significance of these two groups of competences in job acquisition, how useful they are in a given job and what their role in career development is. Some researchers claim that vocational/ occupation-specific skills are of key importance, while other authors underline the importance of general (or generic) skills in this process (Bowen 1977). For instance, Bishop (1989) claims that vocational competences are those which first and foremost determine the high value of university graduates. At the same time he also states that in times of high competition and an oversupply of degree holders, these competences are complementary and do not alone make job seekers with university education competitive in their job search (Kang \& Bishop 1989).

Other researchers appear to support the view that practical education and vocational competences play a major role, in particular to the successful transition of recent graduates (e.g. Vaatstra \& Vries 2007; GarciaAracil \& Van der Velden 2008; Gibbs et al. 2011). Academics stressed the role of general academic competences for guaranteeing a more hopeful situation of graduates on the labour market (e.g.: Stasz et al. 1993). They claim that screening or sorting theories are key in the process of candidate selection by prospective employers (Thurow 1979). There is also empirical research which proves that it is pointless to try and estimate which of the two competence groups determine 
graduates' situations on the labour market as each of them affects different aspects. Research into adjustment to the requirements of the job and the performance in the job by graduates on the labour market showed that "vocational competencies positively influence the chance of graduates of being matched to an occupation inside the own domain and generic competencies positively influence both the chance of being matched to an occupation outside the own educational domain and the training participation" (Heijke et al. 2003: 227).

Furthermore, certain groups of competences may be important in the process of entering the job market and different competences will be helpful in further career development, i.e. "specific competence may be considered especially relevant as an entrance ticket to the labour market, whereas generic competence may be considered more important for the longer term" (Semeijn 2005: 1-2). Many competences such as analytic competences, working independently and working in a team, positively contribute only to the development of the later careers of graduates (Vaatstra \& Vries 2007).

Another important research area is also the impact of specific competences on graduates' transition results, the quality of the transition and the success of their ongoing professional career. Until now this topic was investigated usually in retrospective studies, i.e. when working graduates were asked to assess their competences (level, relevance for the job) (e.g. Heijke \& Ramaekers 1998; Heijke et al. 2003; Jaunzeme 2006; SalasVelasco 2010). This is how a dependence between certain competences and remuneration was established. Among professions which commonly used participative and methodological competences, remuneration was highest, while professions which relied on organisational skills, applying rules and physical competences, were paid lowest. What is more, specialist competences proved to be sought-after, but employees who had specialist knowledge did not enjoy higher remuneration. This was mainly due to the fact that these specialist competences were mainly used in traditional jobs in the public sector (Garcia-Aracil \& Van der Velden 2008). It was also established that the quality of competences has an impact on employment terms. Highly specialist competences have an influence on getting a good job, but finding one is also much more demanding (Semeijn et al. 2006).

On the other hand, research that looked into how certain competences are relevant for professional careers led academics to conclude that the three most important areas are the following: strengthening their own capacities like, for example using time efficiently or performing well under pressure; mobilising others i.e. working productively with others, coordinating activities, making meaning clear to others and having good specialist knowledge (Salas-Velasco 2010). Mastery of given skills during education is, however, nearly always deficient when juxtaposed with what is required of young employees in their first job (Jaunzeme 2006). It has been recognised that one's success on the labour market is to a large extent determined by certain competences, i.e. communication skills, leadership, customer focus, understanding, emotional intelligence (Stasz 2001). In non-English speaking countries, being able to speak English was a key factor for successful transition (Alias et al. 2013).

Surveys of employers established a list of competences and requirements which were most desired and useful from their point of view. These included computer literacy, effective time management and being able to work in a team environment. In their selfassessment, the majority of graduates stated a mastery of the above competences, but they reported shortcomings in terms of knowledge of their own discipline and the ability to work under pressure. Young employees with higher education stated that they were overcompetent in language skills, in particular when it comes to English. Graduates claimed that their knowledge of the language was not sufficiently utilised in their currently held position (Allen \& Van der Velden 2007). 
Studies of Polish literature revealed a research gap in the identification of higher education graduates' self-assessment of their own competences and the role which acquired competences play in the transition (Piróg 2015). Thus far, the subject of the relevance of graduates' competence to their functioning on the labour market has only been explored in Poland in the summary reports published as part of the Study of Human Capital in Poland. Those reports explore competences in general terms; they relate to higher education graduates in selected aspects only. However, they do not attempt to identify a relationship between competences mastered by students and their subsequent position on the Polish labour market after graduation (Strzebońska \& Dobrzyńska 2011; Górniak 2014).

\section{Competences of geography graduates: Existing research}

In Europe the role of competences in facing the challenges of the labour market in relation to geography graduates was stressed by Clark and Higgitt (1997), Richardson and Solís (2004). However, there is little empirical research in this field. To date, research in this area has revealed that geography studies equip graduates with insufficient competences (in the view of both graduates and employers) while offering knowledge which was excessively broad and detailed. Academic knowledge, while seen as a priority by teachers in geography degree university programs, was marginally relevant in recruitment for almost any job. A far more important factor for successful job-seeking was skills, while competences were crucial for retaining jobs. The competences which proved most relevant in job-seeking while having been insufficiently developed (or completely neglected) during geography studies were: ICT, leadership, mediation and moderation (50\%) and selfmotivation, communication, creativity and team working (40\%). More in-depth analyses demonstrated that physical geography major graduates felt well equipped to start working in jobs which were in line with their education subject. Spatial planning major graduates were the most concerned about their ability to meet the demands in their future jobs (Gedye et al. 2004). The European international research which covered geographers was the TUNING project conducted in 2004/2005. This project came up with the first set of key competences which were most valued by employers among prospective employees, graduates of Earth science degrees (Donert 2007).

Interest in geography graduates' competences is high among American researchers. The development of such research was largely motivated by the will to demonstrate to students, their parents, employers, politicians, and the general public that it was worthwhile to study for a geography degree and that the skills acquired in geography studies were useful in various areas of everyday life.

According to the EDGE project survey results (the Enhancing Departments and Graduate Education) led by the Association of American Geographers, geography graduates are equipped with wide-ranging skills that are relevant for a variety of career pathways (Solem et al. 2008). The most important ones include skills related to time management, teamwork, writing, computer technology and critical thinking. On the other hand, it might prove problematic to transfer skills normally acquired during a work experience, especially to transfer them to non academic work environments where cultures and expectations differ considerably in practical terms. Thus, the research pointed out to the need for geography study programs to focus more on the graduates' transferable skills and ways of communicating their abilities to varied audiences and employers as well as to develop those skills through applied practice in different contexts (Solem et al. 2013: 110-111).

Another important study of competences acquired by geography students is the research carried out under the Geospatial Management Competency Model (GMCM). This model specifies 74 essential competencies 
and 18 competency areas that characterise the work of the most successful managers in the geospatial industry. In the model, geography studies were listed among the university programs which equip their graduates with academic skills, mainly in geographic information systems (GIS), cartography, spatial statistics and field methods, which are fundamental for the geospatial industry. GIS skills make it possible to acquire, manage, display, and analyse spatial data in digital form. Cartography skills are fundamental for producing, creating, and designing paper or digital maps. Fluent skills in field methods play a crucial role in conducting interviews, preparing questionnaires, doing observations, interpreting photographs, etc. Using quantitative methods is important in making calculations, models, and inferences about space, spatial patterns, and spatial relationships (DiBiase et. al. 2010: 60, 69).

In Poland to date, competences of geography graduates were the subject of academic analyses by geography education experts, as documented by the work of W. Osuch. He conducted research to explore the selfassessed competences of students planning a career in teaching and active geography teachers; however, his study did not look at the impact of competences on success in finding a job (Osuch 2010). Another published study aimed to identify the competence level of geography teaching degree holders and how useful those competences were in those graduates' work. The study showed that geography graduates' competences most valued by their employers were: the ability to apply theoretical knowledge in practice, the ability to use information technologies, the ability to seek information in various sources, and the use of one's theoretical background in practical activities (Piróg \& Piróg 2007). Still another study diagnosed the self-assessed key competences and distinguishing competences of geography graduates of the Pedagogical University of Kraków, Poland (Piróg 2011).

\section{Methodology}

The empirical data necessary to meet the objective of the study was collected through a diagnostic survey. The survey consisted of two stages: stage one took place between May and June 2011 and stage two encompassed January and February 2012. During the first stage, the survey was distributed in paper form and the second stage encompassed an online survey. The first stage of the study was addressed to students graduating from full time geography degree programmes in the academic year 2010/2011 in all fourteen higher education institutions which offer geography studies in Poland. The objective of this stage of the research was to diagnose (among others) self-assessment of competences acquired during the educational process.

The set of competences to be included in the survey was created in several stages. First, competences closely related to those from the TUNING project (Donert 2007) were tested. Next, the set of competences was subject to a final verification, drawing on the research experience of specialists from other countries who looked into students and graduates of geography (Gedye et al. 2004; Baylina \& Villanueva 2011). The final set was further tested during a pilot project on 120 people who graduated from geography degree programmes in Kraków in 2011.

In this way a list of 21 competences was created. They were used during a Polandwide survey on the impact of competences on job seeking efforts shortly after graduation (see Tab. 1).

Written consent to conduct the survey was received from twelve out of fourteen higher education institutions. In stage one, with the help of heads and academic staff of the given faculties, face-to-face meetings were held with students of each higher education institution. The survey was confidential but not anonymous as the respondents had to fill in their email addresses in the questionnaire. 1347 surveys were collected via this 
Table 1. Categories of competences subject to geographers' self-assessment

\begin{tabular}{|c|c|c|c|}
\hline \multicolumn{4}{|c|}{ Groups of competences } \\
\hline specialised & specific & generic & socio-emotional \\
\hline $\begin{array}{l}\text { - conducting research, } \\
\text { including fieldwork } \\
\text { - solving of geography- } \\
\text { related problems }\end{array}$ & $\begin{array}{l}\text { - cooperation with } \\
\text { people from different } \\
\text { cultures } \\
\text { - entrepreneurial coop- } \\
\text { eration } \\
\text { - IT skills, including GIS }\end{array}$ & $\begin{array}{l}\text { - ability to apply the } \\
\text { acquired knowledge } \\
\text { in practice } \\
\text { - analysis and synthesis } \\
\text { - creativity } \\
\text { - critical assessment } \\
\text { - planning and executing } \\
\text { - projects } \\
\text { - } \text { public speaking and writing } \\
\text { in a foreign language } \\
\text { - team cooperation } \\
\text { - the will to succeed } \\
\text { - time management }\end{array}$ & $\begin{array}{l}\text { - ability to quickly adapt } \\
\text { - } \text { to new situations } \\
\text { - leadership skills } \\
\text { - negotiation and inter- } \\
\text { personal communica- } \\
\text { tion skills, } \\
\text { - precision and attention } \\
\text { to detail in executing } \\
\text { tasks } \\
\text { - responsibility }\end{array}$ \\
\hline
\end{tabular}

channel, which accounts for approximately $78 \%$ of all graduates from full time geography degree programmes in the academic year 2010/2011. The respondents represented all student types, i.e. undergraduates (bachelor's degree), postgraduates (2 year master's degree) and students of long-cycle five-year master's programmes ${ }^{4}$, which were still running at the time in some universities.

The second stage of the study was conducted approximately six months postgraduation. An online survey was sent to all respondents who in stage one declared plans to seek employment immediately after graduation. 597 respondents declared in stage one that they were planning to look for a job after graduation and all of them received an electronic invitation to participate in the second stage of the project. The invitation included a link with an individual password necessary to log into the database. The objective of this stage was, among others, to examine the situation of graduates on the labour market, look into the job market entry mechanisms and in the case of working graduates - to find out more about their working conditions.

The relatively short, six month period between the two stages was chosen for

\footnotetext{
${ }^{4}$ A five-year-long rolling master's degree programme without the possibility to graduate in the meantime with an undergraduate degree.
}

a number of reasons. Firstly, a period of six months since the official cessation of studies is the period most often used to analyse the speed and characteristics of the transition process from academic education to professional career (Müller \& Gangl 2003). Moreover, it is shortly after graduation when competences acquired during a course of study are at the peak of their powers and still fresh in the memory as this capital was heavily invested in during the course of study. Therefore, it is in this timeframe when educational capital has the strongest positive impact possible on the professional future of graduates. Furthermore, the longer one remains unemployed after graduation, the higher the risk of deterioration of these competences (Rożnowski 2009).

The collected statistical data from two databases (from stage one and two) was used to generate a single output database. The email addresses were unique keys which explicitly identified each respondent at the moment of graduation and approximately six months later. The connected databases underwent formal and technical control measures in order to find out any possible mistakes or discrepancies. As a result, a set with complete data from 375 graduates was extracted translating into a responsiveness rate of $68.2 \%$. This personalised collective group of graduates was the study group 
which was subjected to further in-depth statistical quantitative and qualitative analysis. The group consisted of representatives of all degree types in nearly equal measures, i.e. graduates of undergraduate bachelor's programmes accounted for $32.5 \%$, postgraduates accounted for $32.0 \%$ and graduates of long-cycle five-year master's programmes accounted for $35.5 \%{ }^{5}$.

\section{Findings}

\section{Self-assessment of one's competences and transition outcome}

The respondents were asked to self-assess their mastery of the above listed $21 \mathrm{com}$ petences on a scale from 1 to $6^{6}$. Bearing in mind that successful entry into the job market may be interpreted in a variety of ways, current methodological recommendations were used to select what would be subject to analysis. Besides the actual status of the graduate (employed/unemployed), other elements that had to be established included:

- to what extent graduates use their educational capital acquired at university in their job. This was analysed by establishing how related their current position was to their level of education and field of study;

- remuneration which gives us an idea about how probable it is that a graduate can make the actual transition to the adult world of financial independence;

- professional development prospects which was, among others, assessed by the position held;

- level of satisfaction and subjective feeling of contentment with one's job (Müller \& Gangl 2003; Raffe 2008; Gajderowicz et al. 2012).

5 The research did not include employers. This resulted from the objective of the entire research programme, in which the exploration of competences was one of many elements analysed in order to identify the directly modifiable determinants of recent graduates' transition into the labour market.

6 Grading scale: 1 - unsatisfactory; 2 - acceptable; 3 - satisfactory; 4 - good; 5 - very good; 6 - excellent.
For the purpose of analysing the relationship between self-assessment of competences and the given elements of transition, the competences were broken down into: specialised, specific, socio-emotional, generic (Baylina \& Villanueva 2011) (cf. Tab. 1).

The studied graduates on average assessed their own competences acquired during the course of study relatively high (average of 3.97). The top five mastered competences included: autonomy, team cooperation, solving of geography-related problems, conducting fieldwork research, analysis and synthesis. The respondents felt least confident in speaking and writing in a foreign language, entrepreneurial cooperation, leadership skills, IT skills and cooperation with people from different cultures.

As regards terms of employment, the survey highlighted a relationship between the self-assessment of certain groups of recent geography graduates' competences and remuneration. Respondents who declared high earnings in a Polish context, i.e. higher than 2,500 Polish zloty per month (approx. 620 Euro) also on average assessed their competences highest: 4.5 for specialised. People, who earned even more, assessed their specialized (6.0), socioemotional (4.0) and key competences (4.0) very highly. Therefore, it can be stated that the high assessment of the above mentioned groups of competences facilitated acquiring a better paid job. Yet again, specialised competences proved to be the most significant. In lower remuneration brackets, no relationship between the self-assessment of one's competences and salary was observed.

The self-assessment of competences, but only those from the specialised category, had a partial impact on getting a job related to the field of study. Respondents who assessed their specialised skills highly more often found employment which was related to their degree and level of education. The performance of other groups of respondents was not a determining factor in transition.

Similarly, the clearest relationship was noticed between specialised competences 
Table 2. Self-assessment of one's competences and selected transition outcomes (arithmetic mean)

\begin{tabular}{|c|c|c|c|c|c|}
\hline \multirow[b]{2}{*}{ Question } & \multirow[b]{2}{*}{ Answer } & \multicolumn{4}{|c|}{ Competences } \\
\hline & & 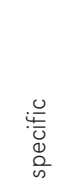 & 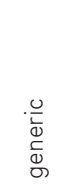 & 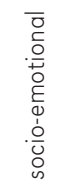 & 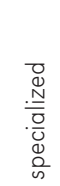 \\
\hline \multirow[t]{8}{*}{ Remuneration } & less than 1,000 PLN & 3.82 & 4.07 & 4.28 & 4.49 \\
\hline & 1,001 - 1,500 PLN & 3.59 & 3.94 & 4.27 & 4.47 \\
\hline & 1,501 - 2,000 PLN & 3.65 & 3.95 & 4.11 & 4.51 \\
\hline & $2,001-2,500$ PLN & 3.53 & 3.99 & 3.89 & 3.89 \\
\hline & $2,501-3,000$ PLN & 4.50 & 4.13 & 3.00 & 4.00 \\
\hline & $3,001-3,500$ PLN & 3.67 & 3.50 & 3.40 & 4.67 \\
\hline & $3,501-4,000$ PLN & 4.00 & 4.00 & 4.00 & 6.00 \\
\hline & over 4,000 PLN & 3.81 & 4.65 & 4.55 & 5.25 \\
\hline \multirow{4}{*}{$\begin{array}{l}\text { Are you satisfied } \\
\text { with the job? }\end{array}$} & definite yes & 3.98 & 4.13 & 4.06 & 4.52 \\
\hline & rather yes & 3.50 & 3.93 & 4.10 & 4.59 \\
\hline & rather no & 3.55 & 3.84 & 4.02 & 4.37 \\
\hline & definite no & 3.74 & 4.03 & 4.33 & 4.21 \\
\hline \multirow{4}{*}{$\begin{array}{l}\text { Is a job related } \\
\text { to the degree? }\end{array}$} & definite yes & 3.66 & 3.90 & 4.20 & 4.62 \\
\hline & rather yes & 3.49 & 3.96 & 4.20 & 4.58 \\
\hline & rather no & 3.70 & 3.92 & 4.09 & 4.58 \\
\hline & definite no & 3.64 & 3.97 & 4.09 & 4.30 \\
\hline \multirow[t]{4}{*}{ Position } & assistant (office staff and other entry-level positions) & 3.65 & 4.01 & 4.14 & 4.52 \\
\hline & specialist, other independent position & 3.68 & 3.90 & 4.08 & 4.09 \\
\hline & medium level managerial position & 2.35 & 3.42 & 3.12 & 4.60 \\
\hline & other & 3.70 & 3.89 & 4.25 & 4.44 \\
\hline
\end{tabular}

and the position held. Again, respondents working at managerial positions evaluated their own skills higher at the time of graduation than those who ended up working in less attractive jobs.

Finally, there is a relationship between job satisfaction and assessment of competences. People with higher self-assessment of their specialised and socio-emotional competences were more likely to be 'definitely unhappy' with their work than those whose assessment was lower in this area. This result is mostly due to the fact that only a relatively small group of graduates found employment that matched their level of education and the discipline they studied. On top of that, if they assessed their own skills highly, the more disillusioned and unhappy they were (Piróg 2014). For the same reason, graduates who assessed their specific competences as high were less likely to be unhappy with their job because they were more likely to work in jobs closely related to their degrees (Tab. 2).

To sum up, it can be concluded that while transition outcomes among the studied group of graduates was not determined by the level of competences acquired during education, there is some relationship between the transition and self-assessment of these competences. Research results suggest that in Poland, specialised competences have the strongest impact on terms of employment. 


\section{Key competences for predicting graduates' situation on the labour market}

Graduates who comprised the research group were subjects of empirical investigation regarding which competences have an impact on their situation on the labour market. The variables were subject to a forward stepwise discriminant analysis using Statistica software. This method makes it possible, among others, to identify variables which divide the population under research into natural subsets; in the present case, the subsets of working graduates and jobless graduates. The division is done precisely by an analysis of a combined and simultaneous impact of a set of independent variables. This type of analysis was used as it allows one to determine which variables discriminate the given set and divide it into natural groups - the group of working and unemployed graduates in this case. The division was based on the collective and coexisting impact of several or more independent variables whose interrelationship was the core of educational capital (Klecka 1980; Radkiewicz 2010).

Analysis parameters between discriminant variables from the group of competences are illustrated in Table 3.

Table 3. Summary of discriminant function analysis

\begin{tabular}{|l|c|c|c|c|c|}
\hline \multicolumn{1}{|c|}{ Variables } & Wilk's lambda & F to remove & $\begin{array}{c}\text { Statistical } \\
\text { significance }\end{array}$ & Tolerance & $\begin{array}{c}\text { 1-toler. } \\
\text { R-squared }\end{array}$ \\
\hline $\begin{array}{l}\text { Speaking and writing in a foreign } \\
\text { language }\end{array}$ & 0.941 & 4.391 & 0.037 & 0.845 & 0.155 \\
$\begin{array}{l}\text { Solving of geography-related } \\
\text { problems }\end{array}$ & 0.947 & 6.819 & 0.009 & 0.830 & 0.170 \\
$\begin{array}{l}\text { Precision and attention to detail } \\
\text { in executing tasks }\end{array}$ & 0.941 & 4.194 & 0.041 & 0.716 & 0.284 \\
$\begin{array}{l}\text { Time management } \\
\text { The will to succeed }\end{array}$ & 0.938 & 3.024 & 0.083 & 0.623 & 0.377 \\
$\begin{array}{l}\text { Responsibility } \\
\text { Team cooperation }\end{array}$ & 0.941 & 4.203 & 0.041 & 0.663 & 0.337 \\
$\begin{array}{l}\text { Cooperation with people from } \\
\text { different cultures }\end{array}$ & 0.937 & 2.683 & 0.102 & 0.670 & 0.330 \\
$\begin{array}{l}\text { Critical assessment } \\
\text { Negotiation and interpersonal } \\
\text { communication skills }\end{array}$ & 0.935 & 2.131 & 0.145 & 0.694 & 0.306 \\
& 0.934 & 1.586 & 0.146 & 0.724 & 0.276 \\
\hline
\end{tabular}

Relatively significant predictors of transition outcome included specialised skills, knowledge of a foreign language, will to succeed as well as precision and attention to detail in executing tasks. Other variables recorded significance levels higher than the critical value of 0.05 which means they did not show statistical significance in discrimination between the studied groups.

Moreover, the model also took the following competences into account: time management, cooperation with people from different cultures, critical assessment of oneself and others, responsibility, negotiation and interpersonal communication skills. Other competences were not included in the model.

Calculation results let the author conclude that competences have a weak discriminatory power in respect of the respondents' transition prospects, i.e. they did not clearly divide the graduates into those who 'have a chance to find employment' and those 'with little chance of finding employment'. This is due to a high Wilk's lambda value which amounted to 0.9300 (Tab. 4). criminant function amounted to -0.269 for unemployed and $+0,277$ for working graduates.

To sum up, the highest individual contributors to predicting graduates' situation
Average canonical variables of the dis- 
Table 4. Test for statistical significance of discriminant variables.

\begin{tabular}{|l|c|c|c|c|c|c|}
\hline Function & Eigenvalues & $\begin{array}{c}\text { Canonical } \\
\text { correlations }\end{array}$ & Wilks' lambda & Chisquared & $\begin{array}{c}\text { Degrees } \\
\text { of freedom }\end{array}$ & $\begin{array}{c}\text { Significance } \\
\text { of } \mathrm{F}\end{array}$ \\
\hline 0 & 0.075241 & 0.264529 & 0.930024 & 26.69632 & 10 & 0.002908 \\
\hline
\end{tabular}

and their inclusion in either the unemployed or working group were: speaking in foreign language, team cooperation, precision and attention to detail and interpersonal communication skills. The more often these features (high self-assessment of linguistic skills, cooperation with people from different cultures, responsibility, leadership skills) were indicated by the respondent, the higher the likelihood of them belonging to the 'working' group (Tab. 5).

Table 5. Standardised coefficients for canonical variables

\begin{tabular}{|l|r|}
\hline \multicolumn{1}{|c|}{ Variables } & Function \\
\hline $\begin{array}{l}\text { Speaking and writing in a foreign } \\
\text { language }\end{array}$ & -0.449 \\
$\begin{array}{l}\text { Solving of geography-related } \\
\text { problems }\end{array}$ & 0.563 \\
Precision and attention to detail & -0.477 \\
in executing tasks & 0.435 \\
Time management & -0.496 \\
The will to succeed & 0.395 \\
Responsibility & -0.346 \\
Team cooperation & 0.338 \\
Cooperation with people from & \\
different cultures & 0.278 \\
Critical assessment & -0.282 \\
Negotiation and interpersonal & \\
\hline
\end{tabular}

\section{Conclusions}

The theoretical and empirical papers published so far and analysed in the current article indicate that competences have a significant impact on the situation of graduates on the labour market. Previous research highlighted the significance of competences for remuneration and job satisfaction. These findings have been also positively verified in empirical studies.
The empirical research conducted during the present project showed no relationship between Polish geographers' assessment of their own competences and their situation on the labour market. A negligible relationship was discovered between self-assessment and terms of employment, with specialised competences having the most impact. A high self-assessment of these skills resulted in a higher likelihood of finding work which corresponds to education level, slightly higher pays and generally holding more attractive posts. Discriminant function analysis, on the other hand, indicates that while competences are not significant for predicting transition outcomes, the strongest individual predictor of ending up working/unemployed was shown by key and socio-emotional skills, i.e. public speaking, team cooperation, precision and attention to detail and interpersonal communication skills.

Based on these results, one can formulate a conclusion that, given the current oversupply of university graduates, their chances of finding employment become higher, the better their mastery of key and socio-emotional skills. However, finding a job closely related to one's field of study and with relatively better terms of employment is largely dependent on high self-assessment of specialised skills. It is worth noting, however, that the current analysis of the Polish labour market appears to show that graduates who gave a higher evaluation of these skills found better terms of employment not merely because the demand for such specialists was high (Piróg 2014). Instead it may be related to a deeply rooted higher education model which puts the primary focus on knowledge and related specialised skills. These are mastered best by the highest achieving students who then prove to be relatively more successful on the challenging job market. 
The results of the present study appear to illustrate how the basic problems of all jobseekers have grown in severity. In particular, these problems refer to the group of higher education graduates who face the issue of oversupply of employees with similarly high formal qualifications, as well as the structural, mindset, behavioural and institutional mismatch of their competences and the current needs of employers (e.g.: Barone \& Ortiz 2011).

Post-communist countries in Europe have experienced a troublesome situation for graduates for similar reasons as Poland. The difficulties are not only due to the economic downturn and the very high supply of university degree holders, but also a lack of history of cooperation between academia and employers, as well as insufficient understanding of the nature of the labour market (Jaunzeme 2006; Korka 2010; Piróg 2013). These phenomena trigger undesirable, social and individual costs. Performing tasks below one's competence level acquired during academic education, constitutes a partial financial loss of public and/or private means invested in education. Moreover, candidates with degrees compete for the same positions as those with lower education levels, but perfectly sufficient for the given job. Consequently, people without a degree are forced out of the market by university graduates and are unsuccessful in applying for positions matching their qualifications.

Due to the situation on the labour market, graduates' high level of competences do not trigger successful transition. In a wider higher education context, this may exacerbate the loss of interest in taking up higher education at a given university or faculty or the complete loss of interest in degree programmes. This situation should give some food for thought as to whether universities should make more effort to transform their non-material resources into skills that might be valuable in transition. Another reflection which comes to mind is to consider whether, in the current turbulent labour market situation, universities should ensure better corre- spondence between learning outcomes and the current requirements of the job market.

Engagement in ensuring the smoothest and most satisfactory transition of graduates is an important factor in providing high quality education which also improves the status of the given degree programme on the educational services market. This is why universities should develop both student specific competences, closely related to the discipline of study and transferable competences. Specific competences are a particularly valuable and unique capital and, provided they are developed at the most optimum level possible and properly presented, will become a significant component of transitional capital regardless of other conditions. Transferable competences are key for being able to adapt to work at different positions and taking up new challenges. This is crucial in the current situation. Promotion of graduates' competences also cannot be neglected. It has been proven that the better the reputation of the university (particularly in the opinion of employers) and the clearer the profile of the prospective employee defines their set of specific competences, the higher the graduate's chances of successful transition (Solem et al. 2013).

Matching is also of crucial importance. It has been empirically verified that higher matching improves graduates' chance of finding employment (Teijeiro et al. 2013). Another important action to be taken in this area is to engage employers in the process of academic education (Mason et al. 2009). On the other hand, even graduates who appreciate the skills they developed during their education and their role in enhancing their chances on the job market, valued practical education and on-the-job experience much higher than academic training (Crebert et al. 2004). Therefore, it has been recently recommended to pay more attention, not so much to matching, but improving the competence transfer of graduates (Jackson 2013).

Literature reviews and results of empirical research seem to confirm that in Poland (and many other countries) academic training 
should not follow the model of 'education matched to the requirements of the labour market'. This is because, firstly, the labour market requirements change so quickly over time and geographical location that it is impossible to keep up with the changes in the educational system. Secondly, preparing students for future work is one of universities' key tasks, but it is not the only one. Higher education institutions, however, need to be more 'sensitive' not so much to the needs of the labour market, but to its nature and the dynamic changes that occur within it. This sensitivity should be manifested through constant juxtaposition of academic theories with actual real problems and practical thinking.

\section{References}

Alias M., Kaur G., Yuen C., 2013. Unemployed graduates' perceptions on their general communication skills at job interviews. Procedia - Social and Behavioral Sciences - 6th International Conference on University Learning and Teaching (InCULT 2012), vol. 90, no. 1, pp. 324-333.

Allen J., Van der Velden R., 2007. Transitions from higher education to work [in:] U. Teichler (ed.), Careers of university graduates: Views and experiences in comparatives, Dordrecht: Springer, pp. 55-78.

Barone C., Ortiz L., 2011. Overeducation among European University Graduates: A comparative analysis of its incidence and the importance of higher education differentiation. Higher Education, vol. 61, no. 3, pp. 325-337.

BarWIŃSKA-MatajoWICZ J., 2015. Tranzycyjny kapitał kariery absolwentów szkół wyższych w Polsce - wybrane aspekty teoretyczne i empiryczne. Nierówności Społeczne a Wzrost Gospdarczy, vol. 42, no. 2, pp. 378-398.

Baylina M., Villanueva M., 2011. Challenges, expectations and reality: The adaptation of a geography degree to the European higher education area. European Journal of Geography, vol. 2, no. 1, pp. 12-21.
It is crucial to build a positive relationship with stakeholders within the university's environment and reinforce, or sometimes convince them of the fact that a given degree provides its graduates with a range of specific competences. These competences make them competitive employees, facilitate a smooth entry into the world and help achieve a relatively high social standing which may improve the overall quality of life in the region.

Editors' note:

Unless otherwise stated, the sources of tables and figures are the authors', on the basis of their own research.

BOWEN H.R., 1977. Investment in learning: The individual and social value of American higher education. San Francisco: Jossey-Bass.

BRIDGSTOCK R., 2009. The graduate attributes we've overlooked: Enhancing graduate employability through career management skills. Higher Education Research \& Development, vol. 28, no. 1, pp. 31-44.

Cabrera A.F., Weerts D.J., Zulick B.J., 2005. Making an impact with alumni surveys [in:] D. Weerts, J. Vidal (eds.), Enhancing alumni research European and American perspectives: New directions for institutional research, San Francisco: Jossey-Boss, vol. 126, pp. 5-17.

Clark G., Higgitt M., 1997. Geography and lifelong learning: A report on a survey of geography graduates. Journal of Geography in Higher Education, vol. 21, no. 2, pp. 199-213.

Crebert G., Bates M., Bell B., Partric C., CragNOLINI V., 2004. Developing generic skills at university, during work placement and in employment: Graduates' perceptions. Higher Education Research \& Development, vol. 23, no. 2, pp. 147-165.

DiBiase D., Corbin T., Fox T., Francica J., Green K., JaCkson J., Jefrress G., Jones B., Jones B., Mennis J., Schuckman K., Smith C., Van Sickle J.V., 2010. The new geospatial technology competency model: Bringing workforce needs into focus. Urisa Journal, vol. 22, no. 2, pp. 55-72. 
DONerT K., 2007. Aspects of the State of Geography in European higher education. Tuning geography: A report of findings and outcomes. Liverpool: Herodot Network, Liverpool Hope University.

FERNÁNDEZ C., 2006. The role of education vis-avis job experience in explaining the transitions to employment. Spanish Economic Review, vol. 8, no. 3, pp. 161-187.

Freire J.M., Teijeiro M., 2010. Competences of graduates as an indicator of external quality assurance in universities. Regional and Sectoral Economic Studies, vol. 10, no. 3, pp. 77-91.

Gajderowicz T., Grotkowska G., Wincenciak L., 2012. Determinants of graduates labour market success across domains: A comparative analysis [in:] M. Melink, S. Pavlin (eds.), Employability of graduates and higher education management systems, University of Ljubljana, pp. 66-88.

Garcia-Aracil A., Mora J.-G., Vila L.E., 2004. The rewards of human capital competences for young European higher education graduates. Tertiary Education and Management, vol. 10, no. 4, pp. 287-305.

Garcia-Aracil A., Van der Velden R., 2008. Competencies for young European higher education graduates: Labor market mismatches and their payoffs. Higher Education, vol. 55, no. 2, pp. 219-239.

Gedye S., Fender E., Chalkley B., 2004. Students' undergraduate expectations and post graduation experiences of the value of a degree. Journal of Geography in Higher Education, vol. 28, no. 3, pp. 381-396.

GibBs S., Steel G., Kuiper A., 2011. Expectations of competency: The mismatch between employers' and graduates' views of end-user computing skills requirements in the workplace. Journal of Information Technology Education, vol. 10, no. 1, pp. 371-382.

Górniak J. (ed.), 2014. Kompetencje Polaków a potrzeby polskiej gospodarki. Raport podsumowujacy IV edycję badań BKL z 2013 r. Warszawa: Polska Agencja Rozwoju Przedsiębiorczości.

Heijke H., Meng C., Ramaekers G., 2003. An investigation into the role of human capital competences and their pay-off. Interna- tional Journal of Manpower, vol. 24, no. 7, pp. 750-773.

HeiJke H., Ramaekers G., 1998. The knowledge and skills of economics graduates and their significance on the labour market [in:] W.J. Nijhof, J.N. Streumer (eds.), Key qualifications in work and education, Netherlands: Springer, pp. 221-244.

JACKSON D., 2013. Business graduate employability - where are we going wrong? Higher Education Research \& Development, vol. 32, no. 5, pp. 776-790.

JAUNZEME I., 2006. Employability of university graduates according to their qualifications and competencies: The case of Latvia. http:// www.ufhrd.co.uk/wordpress/wp-content/ uploads/2008/06/414-employability-of-university-graduates-according-to-thei.pdf [1 November 2015].

KANG S., BISHOP J., 1989. Vocational and academic education in high school: Complements or substitutes? Economics of education review, vol. 8, no. 2, pp. 133-148.

Kivinen O., Ahola S., 1999. Higher education as human risk capital. Higher Education, vol. 38, no. 2, pp. 191-208.

KLECKA W.R., 1980. Discriminant analysis. Beverly Hills: Sage Publications.

KORKA M., 2010. Graduate labour market mismatches: New features of an older matter. Review of Economic and Business Studies, vol. 3, no. 1, pp. 13-22.

KRYŃSKA E., 2011. Absolwenci szkół wyższych na rynku pracy. Oczekiwania i rzeczywistość [in:] K. Jędralska, J. Bernais (eds.), Kompetencje absolwentów studiów ekonomicznych: Perspektywa nauki i biznesu, Prace Naukowe. Uniwersytet Ekonomiczny w Katowicach, pp. 87-101.

Mason G., Williams G., Cranmer S., 2009. Employability skills initiatives in higher education: What effects do they have on graduate labour market outcomes? Education Economics, vol. 17, no. 1, pp. 1-30.

McClelland D.C., 1973. Testing for competence rather than for "intelligence." American Psychologist, vol. 28, no. 1, pp. 1-14.

McGuinneSS S., SLOANE P.J., 2011. Labour market mismatch among UK graduates: An analysis using REFLEX data. Economics of Education Review, vol. 30, no. 1, pp. 130-145. 
Müller W., Gangl M., 2003. The transition from school to work: A European perspective [in:] W. Müller, M. Gangl (eds.), Transitions from school to work in Europe, Oxford: Oxford University Press, pp. 1-22.

Nunez I., Livanos I., 2010. Higher education and unemployment in Europe: An analysis of the academic subject and national effects. Higher Education, vol. 59, no. 4, pp. 475-487.

Osuch W., 2010. Kompetencje nauczycieli geografii oraz studentów geografii - kandydatów na nauczycieli. Prace Monograficzne, 570, Kraków: Wydawnictwo Uniwersytetu Pedagogicznego w Krakowie.

PIRÓG D., 2011. Graduates of geographical studies on the labour market in the process of transformation in higher education. Prace i Studia Geograficzne, no. 48, Prace Instytutu Geografii UJK, vol. 18, pp. 161-172.

PIRÓG D., 2013. Absolwenci szkół wyższych na rynku pracy w warunkach kryzysu. Przedsiębiorczość - Edukacja, 9, pp. 302-316.

PIRÓG D., 2014. Destinations of geography graduates in the labour market in Poland and other countries. Geographia Polonica, vol. 87, no. 1, pp. 95-111.

Piróg D., 2015. Przechodzenie absolwentów studiów geograficznych na rynek pracy. Proces, czynniki, predykcja. Prace Monograficzne, 715, Kraków: Wydawnictwo Uniwersytetu Pedagogicznego im. Komisji Edukacji Narodowej.

PIRÓG D., PIRÓg S., 2007. Pożq̨dane umiejętności absolwentów nauczycielskich studiów geograficznych na rynku pracy $w$ procesie przemian społeczno-gospodarczych w Polsce [in:] J. Lach, M. Borowiec, T. Rachwał (eds.), Procesy transformacji społeczno-ekonomicznych i przyrodniczych struktur przestrzennych, Kraków: Wydawnictwo Naukowe Akademii Pedagogicznej, pp. 631-645.

RACHWAt T., 2011. Transformations of the employment structure as an expression of the transformation of Polish industry against the background of the European Union. Bulletin of Geography. Socio-economic series, vol. 15, no. 15 , pp. 5-25.

RadkieWICZ P., 2010. Analiza dyskryminacyjna. Podstawowe założenia i zastosowania $w$ badaniach społecznych. Psychologia Społeczna, vol. 5, no. 2-3(14), pp. 142-161.
Raffe D., 2008. The concept of transition system. Journal of Education and Work, vol. 21, no. 4, pp. 277-296.

Reimer D., Steinmetz S., 2009. Highly educated but in the wrong field? Educational specialisation and labour market risks of men and women in Spain and Germany. European Societies, vol. 11, no. 5, pp. 723-746.

Richardson D., Solis P., 2004. Confronted by insurmountable opportunities: Geography in society at the AAG's Centennial. The Professional Geographer, vol. 56, no. 1, pp. 4-11.

Rożnowskı B., 2009. Przechodzenie młodzieży z systemu edukacji na rynek pracy w Polsce: Analiza kluczowych pojęć dotyczacych rynku pracy u młodzieży. Lublin: Katolicki Uniwersytet Lubelski.

Salas-Velasco M., 2010. Competences possessed by Spanish university graduates and qualification requirements for jobs: Do higher education institutions matter? Skope Research Paper, no. 92, http://www.skope.ox.ac.uk/wordpress/ wp-content/uploads/2014/04/RP92.pdf [2 February 2016]

Semeijn J.H., 2005. Academic competences and labour market entry studies among Dutch graduates. Maastricht: ROA, Maastricht University [Thesis].

Semeijn J.H., Van der Velden R., HeiJke H., 2006. Competence indicators in academic education and early labour market success of graduates in health sciences. Journal of Education and Work, vol. 19, no. 4, pp. 383-413.

Solem M., Cheung I., SChlemper B., 2008. Skills in professional geography: An assessment of workplace needs and expectations. The Professional Geographer, vol. 60, no. 3, pp. 356-373.

Solem M., Kollasch A., Lee J., 2013. Career goals, pathways and competencies of geography graduate students in the USA. Journal of Geography in Higher Education, vol. 37, no. 1, pp. 92-116.

Stasz C., 2001. Assessing skills for work: Two perspectives. Oxford Economic Papers, vol. 53, no. 3, pp. 385-405.

Stasz C., Ramsey K., Eden R., DaVanzo J., FarRIS H., LewIS M., 1993. Classrooms that work: Teaching generic skills in academic and vocational settings. Santa Monica, Calif.: Rand. 
Strzebońska A., Dobrzyńska M., 2011. Kompetencje jako przejaw kapitału ludzkiego [in:] Bilans kapitału ludzkiego w Polsce. Raport podsumowujacy pierwsza edycję badań realizowana w 2011 roku. Warszawa: Polska Agencja Rozwoju Przedsiębiorczości, pp. 26-39.

Teijeiro M., Rungo P., Freire J.M., 2013. Graduate competencies and employability: The impact of matching firms' needs and personal attainments. Economics of Education Review, vol. 34, no. 4, pp. 286-295.

THUROW L.C., 1979. A job competition model [in:] M. Piore (ed.), Unemployment and inflation:
Institutionalist and structuralist views, New York: Sharpe, pp. 17-32.

TURSKA E., 2014. Kapitał kariery ludzi młodych. Uwarunkowania i konsekwencje. Katowice: Wydawnictwo Uniwersytetu Śląskiego.

VAatstra R., VRIES R.D.E., 2007. The effect of the learning environment on competences and training for the workplace according to graduates. Higher Education: The International Journal of Higher Education and Educational Planning, vol. 53, no. 3, pp. 335-357. 